\title{
Tsunami hazard in Lombok \& Bali, Indonesia, due to the Flores backarc thrust
}

\author{
Raquel P. Felix ${ }^{1}$, Judith A. Hubbard ${ }^{1,2}$, Kyle E. Bradley ${ }^{1,2}$, Karen H. Lythgoe ${ }^{2}$, Linlin Li $^{3,4}$ and \\ 5 Adam D. Switzer ${ }^{1,2}$ \\ ${ }^{1}$ Asian School of the Environment, Nanyang Technological University, Singapore \\ ${ }^{2}$ Earth Observatory of Singapore, Nanyang Technological University, Singapore \\ ${ }^{3}$ School of Earth Sciences and Engineering, Sun Yat-sen University, Zhuhai, China \\ ${ }^{4}$ Southern Marine Science and Engineering Guangdong Laboratory (Zhuhai), Zhuhai, China \\ Correspondence to: Raquel P. Felix (raquelpi001@e.ntu.edu.sg)
}

\begin{abstract}
The tsunami hazard posed by the Flores backarc thrust, which runs along the northern coast of the islands of Bali and Lombok, Indonesia, is poorly studied compared to the Sunda megathrust, situated $\sim 250 \mathrm{~km}$ to the south of the islands. However, the 2018 Lombok earthquake sequence demonstrated the seismic potential of the western Flores Thrust when a fault ramp beneath the island of Lombok ruptured in two Mw 6.9 earthquakes Although the uplift in these events mostly occurred below land, the sequence still generated 1-2.5 m-high local tsunamis along the northern coast of Lombok (Wibowo et al., 2021). Historical records show that the Flores fault system in the Lombok and Bali region has generated at least six $\geq$ Ms 6.5 tsunamigenic earthquakes since 1800 CE. Hence, it is important to assess the possible tsunami hazard represented by this fault system. Here, we focus on the submarine fault segment located between the islands of Lombok and Bali (below the Lombok Strait). We assess modeled tsunami patterns generated by fault slip in six earthquake scenarios (slip of 1-5 m, representing Mw 7.2-7.9+), with a focus on impacts on the capital cities of Mataram, Lombok and Denpasar, Bali, which lie on the coasts facing the strait. We use a geologically constrained earthquake model informed by the Lombok earthquake sequence (Lythgoe et al., 2021), together with a high-resolution bathymetry dataset developed by combining direct measurements from GEBCO with sounding measurements from the official nautical charts for Indonesia. Our results show that fault rupture in this region could trigger a tsunami reaching Mataram in $<8$ minutes and Denpasar in 10-15 minutes, with multiple waves. For an earthquake with 3-5 m of coseismic slip, Mataram and Denpasar experience maximum wave heights of $\sim 1.3-3.3 \mathrm{~m}$ and $\sim 0.7$ to $1.5 \mathrm{~m}$, respectively. Furthermore, our earthquake models indicate that both cities would experience coseismic subsidence of $20-40 \mathrm{~cm}$, exacerbating their exposure to both the tsunami and other coastal hazards. Overall, Mataram city is more exposed than Denpasar to high tsunami waves arriving quickly from the fault source. To understand how a tsunami would affect Mataram, we model the associated inundation using the $5 \mathrm{~m}$ slip model and show that Mataram is inundated $\sim 55-140 \mathrm{~m}$ inland along the northern coast and $\sim 230 \mathrm{~m}$ along the southern coast, with maximum flow depths of 2-3 m. Our study highlights that the early tsunami arrival in Mataram, Lombok gives little time for residents to evacuate. Raising their awareness about the potential for locally generated tsunamis and the need for evacuation plans is important to help them respond immediately after experiencing strong ground shaking.
\end{abstract}




\section{Introduction}

Most tsunami studies focus on earthquakes sourced by subduction zones, as they have high potential to generate destructive tsunamis (e.g., Mw 9.1 2004 Sumatra and Mw 9.0 2011 Tohoku earthquakes). Fewer studies focus on tsunamis generated by back-arc thrust faults within the upper plate that accommodate a component of plate convergence (Silver and Reed, 1988). The Mw 7.7 1991 Limon, Costa Rica (Suárez et al., 1995), Mw 7.9 1992 Flores Island, Indonesia, and Mw 7.51999 Ambrym Island of Vanuatu (Regnier et al., 2003) earthquakes demonstrated that back-arc thrusts can generate earthquakes and tsunamis resulting in fatalities and severe damage and destruction to structures. Hence, it is important to study the tsunami hazard associated with back-arc thrusting.

Here, we assess the tsunami hazard associated with the westernmost segment of the Flores Thrust, a back-arc thrust that extends for $>1,500 \mathrm{~km}$, accommodating a portion of the convergence between the Indo-Australian and Sunda Plates (Fig. 1a). Unlike its eastern segment, where the 1992 Mw 7.9 Flores Island earthquake occurred, the western part of the fault has not hosted devastating tsunamis in recent years, although historical records and previous studies show that it has generated at least eight tsunamigenic earthquakes (Fig.1b, NOAA database, Hamzah et al., 2000; Rastogi and Jaiswal, 2006; Musson, 2012; Nguyen et al., 2015, Tsimopoulou et al., 2020. The recent 2018 Lombok earthquake-triggered tsunamis were relatively minor because the earthquakes mostly occurred beneath the island itself and not offshore; nevertheless, the occurrence of the 2018 Lombok earthquakes

55 gives new insights into the activity and geometry of this fault segment, and highlights the risk of earthquakes and associated tsunamis along strike.

Our study focuses on the tsunami hazard caused by slip on the Flores Thrust in the Lombok Strait, a 20-60 kmwide body of water between the islands of Lombok and Bali that connects the Java Sea to the Indian Ocean. Because of its geometry, slip on the thrust in the Lombok Strait could generate tsunamis that would efficiently propagate southwards and hit the west coast of Lombok and the east coast of Bali, where their capital cities (Mataram and Denpasar) are located.

\subsection{Regional setting}

65 Bali and Lombok islands, east of Java, are part of the Lesser Sunda Islands (Fig. 1a). They are located along the volcanic arc of the Java subduction zone, where the NNE-moving Indo-Australian Plate subducts beneath the Sunda Plate (Dewey and Bird, 1970; Hamilton, 1979; Bowin et al., 1980; Silver et al., 1983, 1986; Hall and Spakman, 2015; Koulali et al., 2016). The Java trench lies $\sim 250 \mathrm{~km}$ to the south. The Flores back-arc thrust belt, on the other hand, follows the northern edge of the islands. Here, the kinematics of fault slip and folding are

70 consistent with the sense of movement of the Indo-Australian Plate and associated shortening, indicating that the Flores back-arc thrust also formed to accommodate stress associated with the plate collision (Silver et al., 1983, 1986).

The Flores back-arc thrust is an east-west-trending, south-dipping fault zone that extends for $>1,500 \mathrm{~km}$ along strike. It is composed of two main segments: the Wetar thrust zone to the east and the Flores Thrust to the west (Silver et al., 1983, 1986); Fig. 1a). From east to west, the Flores Thrust traverses just north of central Flores, Sumbawa, Lombok and Bali (Fig. 1a). From central Flores to east of Lombok, the thrust zone reaches to the 
seafloor (Silver et al., 1983, 1986; Yang et al., 2020). As the deformation becomes blind from central Lombok to the west, the thrust zone has been mapped based on folds visible in seismic reflection data, and also manifests as a band of steeper north-facing slope on the seafloor (Silver et al., 1983; McCaffrey and Nabelek, 1987; Yang et al., 2020). West of Bali, folds are fewer and have no to little seafloor expression (Silver et al., 1983; Fig. 1d), suggesting that the Flores Thrust terminates at Bali (Yang et al., 2020). However, GPS measurements show that the north-south convergence rate in Bali $(5 \pm 0.4 \mathrm{~mm} / \mathrm{yr})$ is similar to that onshore Java $(6 \pm 1 \mathrm{~mm} / \mathrm{yr})$, therefore back-arc shortening may continue across a segment boundary along the Kendeng thrust in Java(Koulali et al., 2016).

\subsection{Seismicity of the Flores Thrust}

Focal mechanisms show that from February 1976 to February 2021, the Flores Thrust generated 29 Mw 5.5 to 7.8 earthquakes within the upper $40 \mathrm{~km}$ of the crust (GCMT; Fig. 1a). Earthquakes in this region can be caused by either tectonically driven fault slip or volcanic activity. In this back-arc region, most of the focal mechanisms are characterized by east-west striking nodal planes with a fault plane dipping $26 \pm 8^{\circ} \mathrm{S}$; we infer that these are associated with the Flores Thrust.

This fault system has also produced uplift on its hanging wall. From eastern Sumbawa to central Flores, uplift is recorded by elevated terraces on the northern sides of the islands (Van Bemmelen, 1949). We suggest that the Quaternary reef terraces in northwest Bali (Boekschoten et al., 2000) are also related to tectonic uplift above the Flores thrust system, suggesting that the fault extends all the way to the western coast of the island (Fig. 2).

Although the earthquakes in this region are largely consistent with tectonic shortening, the active volcanoes not only generate their own seismicity, but also play a role in the horizontal and vertical distribution of fault-generated earthquakes (Lythgoe et al., 2021). A relationship between faulting and volcanic activity was observed for the 2018 Lombok earthquake sequence, which generated four $>$ Mw 6 events between $28^{\text {th }}$ July to $19^{\text {th }}$ August. These earthquakes did not occur offshore on the northern frontal thrust of the Flores Thrust, but instead involved slip along the deeper part of the fault and associated imbricate thrusts beneath Lombok, to the north of the active Rinjani volcano (Salman et al., 2020; Yang et al., 2020; Lythgoe et al., 2021). While these earthquakes were not directly caused by volcanic activity, the presence of the volcano constrained the earthquake distribution by elevating the downdip limit of the seismogenic zone in the crust (Lythgoe et al., 2021). Based on relocated earthquakes and seismic reflection data analysis, the earthquakes occurred on the Flores fault ramp, a blind thrust dipping $25^{\circ} \mathrm{S}$ that flattens updip onto the Flores Thrust décollement at $\sim 6 \mathrm{~km}$ depth (Lythgoe et al., 2021; Fig. 1c). 

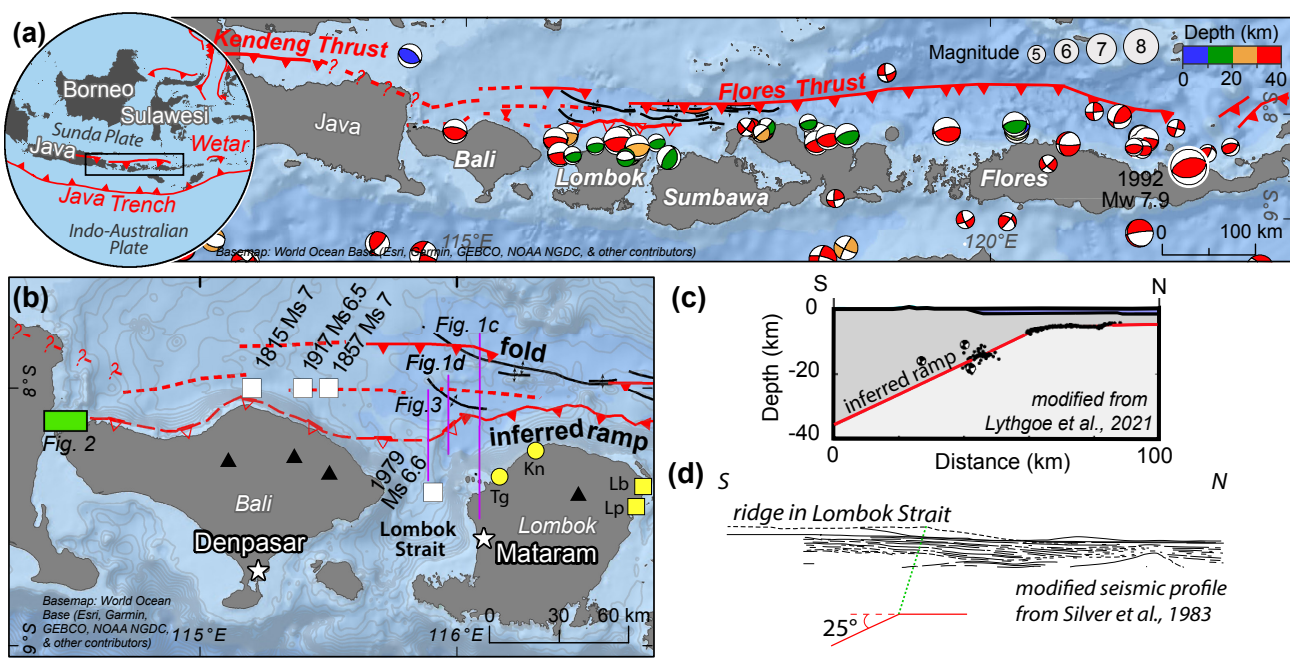

(c)

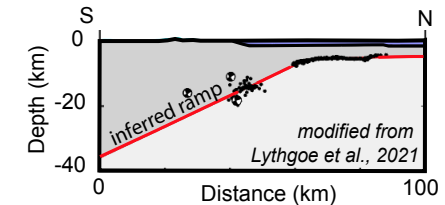

(d) $\mathrm{s}$

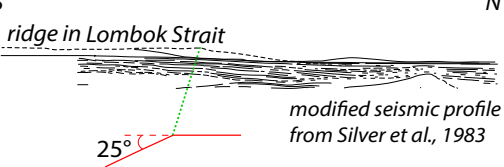

Figure 1: Regional setting of the Flores Thrust and its subsurface ramp-flat geometry. (a) Circle - The Flores back-arc thrust system, which is located along the northern edge of the Lesser Sunda Islands. The thrust is composed of two segments: the Wetar thrust to the east and the Flores Thrust to the west (black rectangle). Seismicity (USGS earthquake catalogue, 1976-2021) and focal mechanism solutions (GCMT, 1976-2021) show that the Flores Thrust is seismically active. The Mw 7.9 Flores Island tsunamigenic earthquake is the largest earthquake on record for this system and occurred at the eastern end of the thrust. (b) The western part of the Flores Thrust has generated historical tsunamigenic earthquakes (white rectangles). Yellow squares and circles: towns where a tsunami was reported following the Mw6.4 $28^{\text {th }}$ July and Mw6.9 $5^{\text {th }}$ Aug 2018 events, respectively. Tg - Tanjung, Kn - Kayangan, Lb Labuhan Pandan and Lp - Leper. We interpret that the blind ramp mapped at Lombok (Lythgoe et al., 2021) extends westwards based on the seafloor morphology and uplifted terraces in the northwestern part of Bali (green rectangle; Fig. 2). Basemaps - World Ocean Base. (c) The geometry of the blind fault ramp is constrained by the seismicity of the 2018 Lombok earthquake sequence (Lythgoe et al., 2021). (d) Gentle folds interpreted by Silver et al., (1983) based on a seismic profile across the Lombok Strait. Below the profile we show our inferred location for the fault ramp.

\subsection{Tsunamigenic earthquakes of the Flores Thrust}

Historical records (NOAA database, www.ngdc.noaa.gov) and tsunami studies (Hamzah et al., 2000; Rastogi and

115 Jaiswal, 2006; Musson, 2012; Nguyen et al., 2015) document at least four tsunamigenic earthquakes on the Flores Thrust, in addition to the two earthquakes in 2018, which produced local inundation (Fig. 1b). Three of these events occurred in the western part of the thrust zone, north of Bali. The oldest event on record is the $1815 \mathrm{Ms} 7$ earthquake, which triggered a landslide and tsunami; together, these events killed $>1,200$ people. NOAA categorizes this as a probable tsunamigenic event, as it is unclear whether the tsunami was caused only by the coastal landslide, or by the earthquake and landslide together. The 1857 Ms 7 and 1917 Ms 6.5 events are described by NOAA as definite and probable tsunamigenic earthquakes, respectively. The 1857 event generated four consecutive tsunami waves, at least $3 \mathrm{~m}$ high, northwest of Flores Island (NOAA, 2021). In addition, in the Lombok Strait, a 1979 Ms 6.6 tsunamigenic earthquake left 200 injured and killed 27 people, although the tsunami is poorly documented and may have played a minor role in the destruction (Hamzah et al., 2000). 
The best-documented tsunamigenic earthquake on the Flores Thrust occurred in its far eastern part (Yeh et al., 1993; Imamura and Kikuchi, 1994; Tsuji et al., 1995; Pranantyo et al., 2021). The 1992 Mw 7.9 Flores Island earthquake injured 2,144 people and killed 2,080 (Yeh et al., 1993; Tsuji et al., 1995; Fig. 1a). This earthquake occurred at $\sim 16 \mathrm{~km}$ depth (Beckers and Lay, 1995), and generated a tsunami that propagated to the northern coast of Flores Island within five minutes (Yeh et al., 1993). Field mapping shows that the tsunami inundated the land as far as $600 \mathrm{~m}$, with an average run-up height of $\sim 2$ to $5 \mathrm{~m}$ (elevation reached above sea level). Anomalously high run-up heights of 20-26 m to the northeast may be associated with submarine landslides (Yeh et al., 1993).

The recent 2018 Lombok earthquake sequence occurred primarily below land, but nevertheless small-scale tsunamis were reported by the residents of northern Lombok (Tsimopoulou et al., 2020). When the Mw 6.4 July event occurred, the northern coast of Lombok subsided by $\leq 0.1 \mathrm{~m}$ (Wibowo et al., 2021), and the northeastern coast was hit by a tsunami at the towns of Labuhan Pandan and Tanjung, which were inundated 10-70 m with run-up heights of $\sim 1-2.5 \mathrm{~m}$. For the Mw 6.9 August 5 event, although the northern coast was uplifted by $\leq 0.5 \mathrm{~m}$ (Wibowo et al., 2021), the residents of the northwest towns, Tanjung and Kayangan, reported a tsunami that inundated 7-40 $\mathrm{m}$ inland with a run-up height of $\sim 1.7-2 \mathrm{~m}$ (Fig. 1b).

Together, these records show that the Flores Thrust is capable of generating significant thrust earthquakes with associated land uplift/subsidence as well as local tsunamis. The full tsunamigenic potential of this fault system is not known, as the observational window is short compared to typical earthquake recurrence intervals. Here, we explore what could happen when coseismic slip occurs on the Flores thrust ramp within the Lombok Strait, and how the generated tsunami and coseismic land deformation would together affect the coastal cities of Mataram, Lombok and Denpasar, Bali.

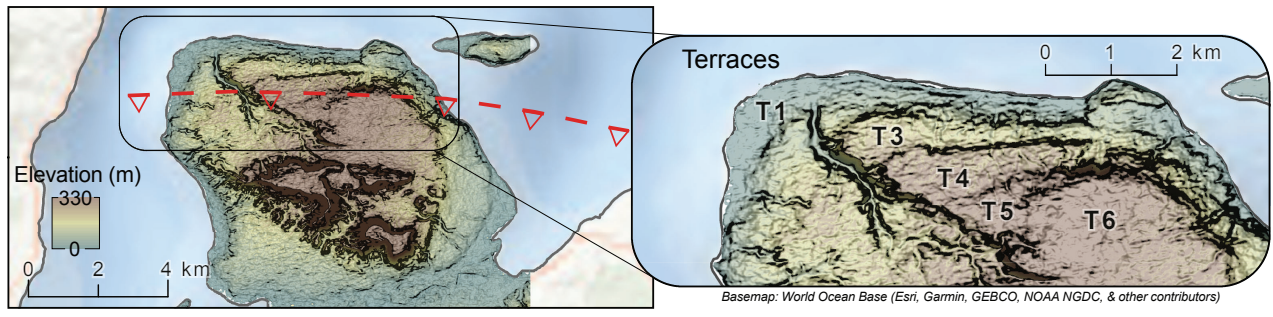

Figure 2: Six coastal terraces (T1-T6) identified using a digital elevation model (DEMNAS) in northwest Bali, likely uplifted due to slip on the Flores Thrust ramp. The location is shown as a green rectangle on the map in Figure 1b. Basemap - World Ocean Base.

\subsection{Previous tsunami modelling studies}

Tsunami modelling studies in this region commonly focus on the segment of the Sunda Megathrust along the

155 Java trench (Okal and Borrero, 2011; Kurniawan and Laili, 2019; Suardana et al., 2019; Kardoso and Dewi, 2021)(Fig. 1a), with a few studies evaluating the western segment of the Flores Thrust (Løvholt et al., 2012; Rusli 
et al., 2012; Afif and Cipta, 2015), and four considering an earthquake sourced within the Lombok Strait (Rakowsky et al., 2013; Horspool et al., 2014; Pradjoko et al., 2018; Wibowo et al., 2021; Fig. 1b). All four studies show tsunami results in Mataram, Lombok; however, each study focuses on different aspects of tsunami modelling, and three predate the 2018 Lombok earthquake sequence, which illuminated important aspects of the fault geometry. The only study after the 2018 earthquakes (Wibowo et al., 2021) did not update their fault model to reflect new information about the geometry of the Flores Thrust derived from studies of the 2018 Lombok earthquake sequence. Overall, these prior results do not address the potential earthquake scenarios that we consider plausible: Rakowsky et al. (2013) study the sensitivity of inundation to land friction, Horspool et al. (2014) describe the probabilistic tsunami hazard, Pradjoko et al.(2018) considers a fault that is much too steep and uses bathymetry that is too coarse to produce reliable results, and Wibowo et al. (2021) did not consider the post-2018 earthquake studies of the fault geometry of the Flores Thrust.

Rakowsky et al. (2013) studied the sensitivity of inundation models in the region to the topography and friction parameters of the land surface. Their tsunami modeling was done using the $\sim 900$-m-resolution GEBCO dataset interpolated with measurements from ships and nautical charts; the interpolation method is not described in detail. They considered an unrealistically large Mw 8.5 earthquake, and produced a maximum flow depth (vertical distance between the land and inundating water surface) of $10 \mathrm{~m}$, with an inundation extent ranging from $\sim 1-1.6$ $\mathrm{km}$ in Mataram. They found that inundation distance depended on the topographic parameters: lower bottom

175 friction or a bare earth digital terrain model produced higher inundation compared to higher friction or a digital surface model (with structures, e.g., houses). Their results highlight the importance of using an accurate surface model when assessing potential inundation.

Horspool et al. (2014) focused on probabilistic tsunami hazard for all of Indonesia. They used a bathymetry dataset that combined GEBCO data with measurements from Navy charts and multibeam surveys. For the western Flores thrust, they set $1 \mathrm{~m}$ of slip on a range of $25-27^{\circ}$-dipping, $10 \times 20 \mathrm{~km}$ sub faults (equivalent to a Mw6.4 earthquake) within the 3-30 km seismogenic depth of the Lombok Strait. Their results do not describe the regional hazard (e.g. wave heights, timing, inundation), but rather assess how much of the local hazard is contributed by this fault system rather than the megathrust. They showed that given an arbitrary 500 -year return period on the fault, 10 $30 \%$ of the tsunami hazard in Mataram is due to the shallow part of the Flores Thrust.

Pradjoko et al. (2018) used a model of a Mw 6.4 earthquake to simulate a scenario similar to the 1979 event, which was the largest recorded earthquake in this region prior to the 2018 Lombok earthquake sequence. They set $2.5 \mathrm{~m}$ of fault slip on a $72^{\circ}$-dipping fault (significantly steeper than the $25^{\circ}$ dip we interpret for the fault) centered

190 at $25 \mathrm{~km}$ depth. Using GEBCO bathymetry to model tsunami propagation (with a coarse horizontal resolution of $\sim 900 \mathrm{~m}$ ), their results indicate that a Mw6.4 earthquake could generate a 0.13-0.2 m-high tsunami wave that arrives at the coast of Mataram $\sim 18-20$ minutes after the earthquake.

The study by Wibowo et al. (2021) focused on the tsunami hazard posed by a Mw 7.4 earthquake on the Flores

195 thrust to the northern coasts of Lombok and Bali. They set 2.7 of slip on a $27^{\circ}$-dipping fault plane with dimensions of $75 \mathrm{~km} \times 27 \mathrm{~km}$ centered at $27 \mathrm{~km}$ depth. The fault parameters they used are based on the mean values of the 
earthquake sources in the USGS 1900-2020 earthquake database. The orientation and depth of the fault are similar to those we use in our modeling, but the updip tip of the fault in their model is located about $25 \mathrm{~km}$ north of the islands rather than along the northern coast of the islands, as we interpret from the 2018 Lombok earthquake 200 sequence and bathymetry in the Strait. They used the 180-m resolution National Bathymetry of Indonesia (BATNAS) dataset as input bathymetry in the numerical simulations. Their focus was on the impact along the northern coasts, but they note that the tsunami arrives in Mataram and Denpasar in 9 and 25 minutes, respectively. They also find that the maximum wave height is $1.5 \mathrm{~m}$ in Mataram and $1 \mathrm{~m}$ in Denpasar.

Following the 2018 Lombok earthquake sequence, we now have a more accurate understanding of the location and subsurface geometry of the Flores Thrust in this region. Hence, the earthquake models we use in our study are geologically well-constrained. In addition, since tsunami propagation in shallow water depends strongly on the bathymetry, we develop and incorporate a new bathymetric model by combining the GEBCO dataset with sounding measurements from the official nautical chart for Indonesia. This is particularly important along the

210 shallow coast, where seafloor roughness has a strong control on wave propagation. In our study, we show the tsunami results from six different earthquake scenarios within the Lombok Strait, highlighting impacts on the populated capital cities of Mataram, Lombok and Denpasar, Bali, as both cities face the Strait. We also calculate the coseismic uplift and subsidence for varying slip amounts, and report this together with the tsunami time history and pattern and the maximum wave height. An inundation scenario is also included for the city of Mataram.

\section{Methodology}

\subsection{Fault model setup}

The 2018 Lombok earthquake sequence illuminated the geometry of the Flores Thrust beneath Lombok (Fig. 1c). Together, relocated aftershocks, earthquake slip distributions, and seismic reflection imaging indicate a blind fault ramp dipping $25^{\circ} \mathrm{S}$ that flattens updip to a décollement at $\sim 6 \mathrm{~km}$ depth and continues north below the Bali Sea. The part of the thrust ramp that ruptured in the 2018 sequence extends $45 \mathrm{~km}$ downdip and $116 \mathrm{~km}$ lengthwise (Lythgoe et al., 2021; Fig. 1c \& 3).

We use these fault parameters to set up our fault model, choosing a fault with an east-west strike, similar to the general trend of the Flores Thrust, positioned across the Lombok Strait. The eastern boundary of the fault is defined by the western limit of the 2018 earthquake sequence. We extend the western edge of the model to below the eastern edge of Bali, in order to span the width of the Strait; the fault likely continues further west (as evidenced by uplifted terraces and seismicity), but rupture to the west would occur below land and would not contribute to a tsunami. We trace the upper blind tip of the fault ramp following the southern edge of a north-facing seafloor slope. This surface morphology coincides with folding interpreted from seismic reflection surveys (Silver et al.,

230 1983; Yang et al., 2020), and we interpret that the folding formed due to slip across a bend at the upper tip of the blind fault ramp (Fig. 1b). We extend the fault ramp to a depth of $25 \mathrm{~km}$ below the seafloor, which represents the maximum seismogenic depth in this region based on historical seismic records and the maximum depth of seismicity observed in the 2018 sequence (Lythgoe et al., 2021).

We model two fault ruptures on this fault (Models A and B, Fig. 3). Model A consists of a whole-fault rupture, 
the 2018 Lombok earthquakes, where most of the slip occurred on the shallow part of the fault ramp. However, the maximum rupture depth at Lombok was interpreted to be limited by the elevated geothermal gradient associated with the volcano. In the Lombok Strait, there is no such volcano; thus, it is likely that slip within the Lombok Strait could reach deeper due to the colder geothermal gradient.

$S$

water depth $(\mathrm{km})$

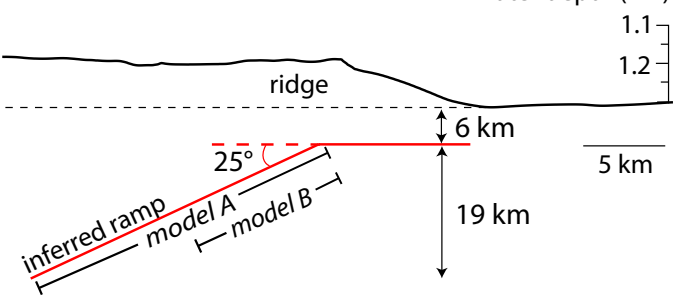

Figure 3: Profile of the fault geometry used in the tsunami modelling relative to the seafloor ridge. We study two fault slip models: model A (whole-ramp rupture) and model B (slip only on the upper half of the ramp). The location of the profile is shown in Fig. 1b.

\subsection{Slip model}

For both Models A and B, we consider three scenarios with uniform slip of 1, 3, and $5 \mathrm{~m}$ (six scenarios total). In order to focus on the impact of tsunami generation, we include only slip on the fault ramp (no slip transferred onto the northern décollement). This updip termination of slip was observed in the Lombok sequence (Lythgoe et al.,

245 2021) and is therefore realistic in our region to the west as well. Although we consider uniform slip, earthquake slip is known to be spatially variable, and in particular to taper around the edges of the slip patch. We evaluate the impact of this taper on the initial seafloor deformation using the Green's function for rectangular dislocations (Okada, 1992) in the code Unicycle (Moore et al., 2019); we find that tapering the slip slightly modifies the uplift profile by broadening it and shifting it to the south (downdip direction) but does not significantly change the model (Fig. 4). 
(a) surface deformation (m)

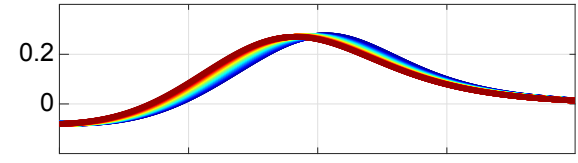

(b) coseismic slip (m)
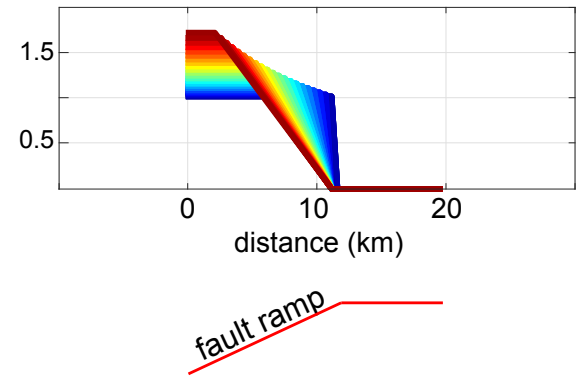

Figure 4: Influence of tapering the updip slip on seafloor deformation. The maximum slip varies across the models in order to preserve the mean slip. (a) The seafloor deformation profiles have similar amplitudes and shapes with slightly offset peaks, even for very significant tapers. (b) Different slip tapers considered. A more gradual taper (red shades) shifts the peak uplift in the downdip direction of the fault ramp. A more abrupt slip taper (blue shades) shifts the peak uplift towards the upper fault bend.

To better translate the models into equivalent earthquakes, we calculate the equivalent Moment Magnitude (Mw) for each modeled event, using a standard rigidity of $30 \mathrm{GPa}$. Since Model A has a wider fault surface, for the same amount of slip, it produces larger magnitudes compared to Model B (Table 1). In each model, we consider only the part of the fault that lies below the Lombok Strait, since this is the part of the fault that is submarine and therefore capable of generating tsunamis. We note that an earthquake rupturing this fault segment could involve slip further along strike, either to the west (below Bali) or to the east (below Lombok, although this part of the fault recently ruptured in multiple earthquakes and is relatively less likely to slip again). Indeed, reaching $5 \mathrm{~m}$ of slip within the Lombok Strait alone would likely require a longer rupture, and therefore a larger magnitude than the values reported in Table 1, given known scaling relationships between fault area and coseismic slip (Wells and Coppersmith, 1994; Hanks, 2002; Biasi and Weldon, 2006; Hanks and Bakun, 2008).

Table 1: Equivalent Moment Magnitudes (Mw) for Models A and B for a given slip amount. Model A ruptures the full ramp while Model B ruptures only the upper half of the ramp. Both models have a fault length of $116 \mathrm{~km}$. The magnitudes here are minima, as each of these events could also include slip on the along-strike part of the fault.

\begin{tabular}{|c|c|c|}
\hline & $\begin{array}{c}\text { Model A } \\
\text { Fault width: } 45 \mathrm{~km}\end{array}$ & $\begin{array}{c}\text { Model B } \\
\text { Fault width: } 22.5 \mathrm{~km}\end{array}$ \\
\hline Slip (m) & \multicolumn{2}{|c|}{ Mw } \\
\hline 1 & 7.4 & 7.2 \\
\hline 3 & 7.7 & 7.5 \\
\hline 5 & 7.9 & 7.7 \\
\hline
\end{tabular}




\subsection{Bathymetry}

Accurate modeling of tsunami wave propagation requires a high-resolution bathymetric map, especially in shallow water. By using detailed bathymetry together with a fine grid size, modelled simulations of tsunami wave heights have been shown to effectively match real near-coast waveforms (Satake, 1995). However, in many parts of the world, high resolution bathymetric data are unavailable. In general, regional tsunami studies use only one bathymetric dataset (e.g., Satake, 1988), commonly either ETOPO (https://www.ngdc.noaa.gov/mgg/global/) or

280 GEBCO (https://www.gebco.net/), because they are publicly available and have wide coverage. However, these datasets have an artificially smooth seafloor (Marks and Smith, 2006), especially at shallow depths, because of the low density of interpolated points (e.g., Fig. 5). In local tsunami studies, the detailed seafloor morphology in shallow water is critical, since seafloor roughness in these regions has nonlinear effects on wave propagation (Wang and Power, 2011). Kulikov et al. (2016) demonstrated that tsunami propagation modeled using the GEBCO

285 dataset results in substantial errors in the estimation of wave propagation.

We generate a high-resolution bathymetric model of the region of interest by combining water depth measurements from GEBCO with sounding measurements from the official nautical charts of Indonesia (http://hdc.pushidrosal.id/). The publicly available GEBCO dataset is provided as an interpolated raster, but also

290 includes the original data points used for interpolation. These data points (water depths) are derived from a variety of sources, both direct (echo soundings, seismic reflection, isolated soundings, electronic navigation chart soundings) and indirect (e.g. satellite altimetry, flight-derived gravity data). Using the Type-Identifier Grid file from GEBCO, which includes the source of the depth data, we identify and extract only the water depths acquired by direct measurement (Fig. 5)

295

The GEBCO data in this region are concentrated along the heavily-travelled ship tracks between the islands of Bali and Lombok, and are too low resolution near the coasts to accurately model tsunami propagation and wave heights (Fig. 5a). We improve the resolution of our bathymetry by digitizing sounding data from the official nautical charts of Indonesia, which are densest in the coastal regions near the cities of Denpasar (Bali) and

300 Mataram (Lombok) and therefore critical for modeling near-shore wave heights in these regions (Fig 5b). We also trace the coastline using the National Digital Elevation Model (DEMNAS, http://tides.big.go.id/DEMNAS/), and cross check it using satellite images from Esri World Imagery (https://www.arcgis.com/).

We combine the water depth measurements from both sources and the coastlines into a single dataset, and then

305 interpolate the data using the 'Topo to Raster' tool in ArcGIS. This tool is based on the ANUDEM program developed by Hutchinson (1989), and generates a continuous digital elevation model based on point data that takes into account the hydrological correctness of the resulting raster. While this method was developed on the basis of subaerial water flow, it has also been used to effectively generate bathymetries for tsunami studies in other regions (Fraser et al., 2014; Darmawan et al., 2020; Wilson and Power, 2020). We note that the shallow

310 shelf regions of the Lombok Strait were likely incised subaerially during the late Holocene sea-level drop (Boekschoten et al., 2000), and their morphologies therefore likely reflect subaerial water flow processes. 
We set the resolution of our interpolated raster to $30 \mathrm{~m}$, as this is similar to the mean distance between the data points along the coasts of Mataram ( 27) and Denpasar ( $\sim 36 \mathrm{~m})$. Our final bathymetry represents a reasonable balance between achievable accuracy at shallow depths and computational efficiency. We validate the interpolated bathymetry by comparing its values with the source data; the mean difference in the shallow regions offshore Mataram and Denpasar is $<0.4 \mathrm{~m}$.
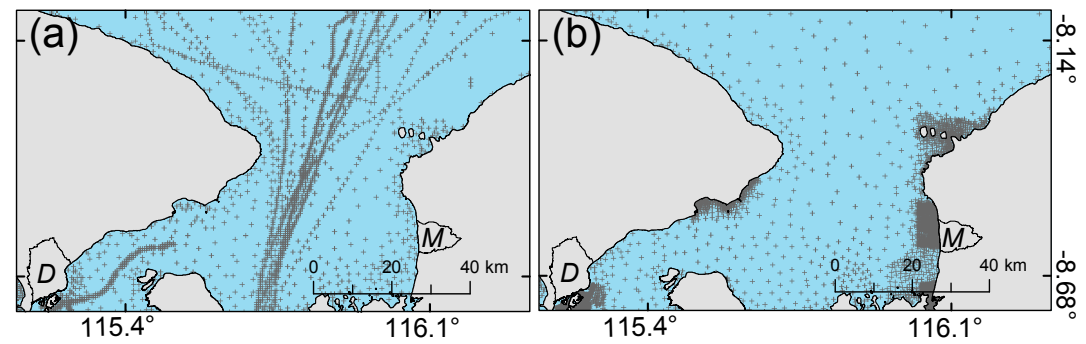

Figure 5: Comparison of the point density of water depth measurements from (a) GEBCO (direct measurements) and (b) nautical charts (soundings). GEBCO data are densest along the center of the Lombok Strait (following ship tracks), while the nautical chart soundings are concentrated near the coastal cities. Combining these data points enhances the accuracy of the resulting bathymetry (shown in Fig. 6). Crosses - locations of measurements. Polygons on land - cities of Denpasar, Bali and Mataram, Lombok. D = Denpasar, $M$ = Mataram.

\subsection{Topography in Mataram, Lombok}

Based on our tsunami model runs, the highest wave heights are observed along the coast of Mataram, Lombok. In order to further explore the tsunami hazard in this populated area (Fig. 6), we model the inundation of the onshore region. The inundation distance and run-up height of a tsunami can vary significantly depending on factors such as the average slope of the coast and the land cover roughness (Kaiser et al., 2011; Griffin et al.,

330 2015); an accurate forecast requires a high-resolution Digital Surface Model (DSM) that maps the buildings and trees.

We use a Digital Surface Model generated by Apollo Mapping based on Pleiades satellite imagery. The DSM has a horizontal resolution of $1.5 \mathrm{~m}$ and a vertical error of $\pm 3 \mathrm{~m}$. This vertical error is the lowest possible for digital elevation models without ground control points, which we do not have access to. We use a DSM rather than a DTM (Digital Terrain Model) to better represent the man-made structures (e.g., houses, infrastructure) present in Mataram city. There are a few areas where the DSM is unavailable along the coast, due to difficulties in data processing associated with tides. We fill these areas with $1.5-\mathrm{m}$ resampled elevation data from DEMNAS, the national elevation model for Indonesia, which has a coarser original horizontal resolution of $8 \mathrm{~m}$. The vertical datum of the merged data is referenced to EGM2008.

In order to run the inundation modelling, the topographic data must be merged with the bathymetry so that the incoming wave can be smoothly modeled across the sea-land interface. To match the resolution of the DEMNASDSM model, we generate another bathymetry model with $1.5 \mathrm{~m}$ resolution in the Mataram region using the same 
345 'Topo to Raster' interpolation method as used previously for the bathymetry. We match the coastlines of the two datasets to generate the final combined model.

\subsection{Tsunami modelling using COMCOT}

We model the tsunami generation, propagation, run-up and inundation using the Cornell Multi-grid Coupled

350 Tsunami (COMCOT) model developed by Liu et al. (1995). This modeling system solves linear and nonlinear shallow water equations using a modified leap-frog finite difference approach (Wang \& Power, 2011). It uses a nested-grid layer algorithm to increase its computational efficiency. The Okada (1985) model is used to calculate surface deformation due to fault slip. We use this model in our study as it has been extensively adopted and validated for modelling tsunami events (e.g., $1960 \mathrm{Mw} 9.5$ Chilean tsunami - Liu et al. 1995; 2004 Mw 9 Indian

355 Ocean Tsunami - Wang and Liu, 2007; 2006 Mw 7.7 South Java tsunami - Tri Laksono et al. 2020; 2010 Mw 7.8 Mentawai earthquake - Hill et al. 2012; 2011 Tohoku tsunami - Chau and Lam, 2015).

For our tsunami modelling, we set up five nested-grid layers in a spherical coordinate system, with finer resolution in the shallow regions along the coasts of Mataram and Denpasar (Fig. 6). The recommended grid size ratio is 3

360 to 5 (Wang and Power 2011), and we want to use a $30 \mathrm{~m}$ resolution layer along the coasts of Mataram (layer 2, Fig. 6) and Lombok (layer 5, Fig. 6). We therefore set the grid size of the main parent layer 1 to $150 \mathrm{~m}$. (Wang and Power, 2011)We create two more sub layers ( $3 \& 4$ ) near Mataram to generate a $1.5 \mathrm{~m}$ grid size to model the inundation. High resolution inundation modeling is computationally expensive, so we only simulate inundation in Mataram for one earthquake scenario: $5 \mathrm{~m}$ slip on fault model A (full width). This represents the "worst case"

365 of our various models. In this modeling, we use the linear shallow water equation in grid layer 1, as it covers the deeper water region, and the nonlinear equation in grid layers 3 to 5 , which target the shallow depths, to incorporate the effect of bottom friction. A Manning's roughness coefficient of 0.013 is used for the water region, and 0.03 on land (Wang \& Power, 2011).

370 We run the tsunami simulation from the time of the earthquake for one hour; this is sufficient to capture both the first wave and a series of smaller, later waves, since the coastal regions we are interested in are close to the source $(<100 \mathrm{~km})$. To observe the tsunami arrival pattern along the coasts of Mataram and Denpasar within the hour, we select virtual tide gauge locations along the 10-m bathymetric contour, facing the coastal areas where dense manmade structures are identified from satellite images. The results of the tsunami modeling are illustrated using maps

375 of the initial sea surface deformation, maximum wave height, coseismic land subsidence in Bali and Lombok, time series of wave arrivals at the virtual tide gauges, and maps of inundation depth in Mataram. 

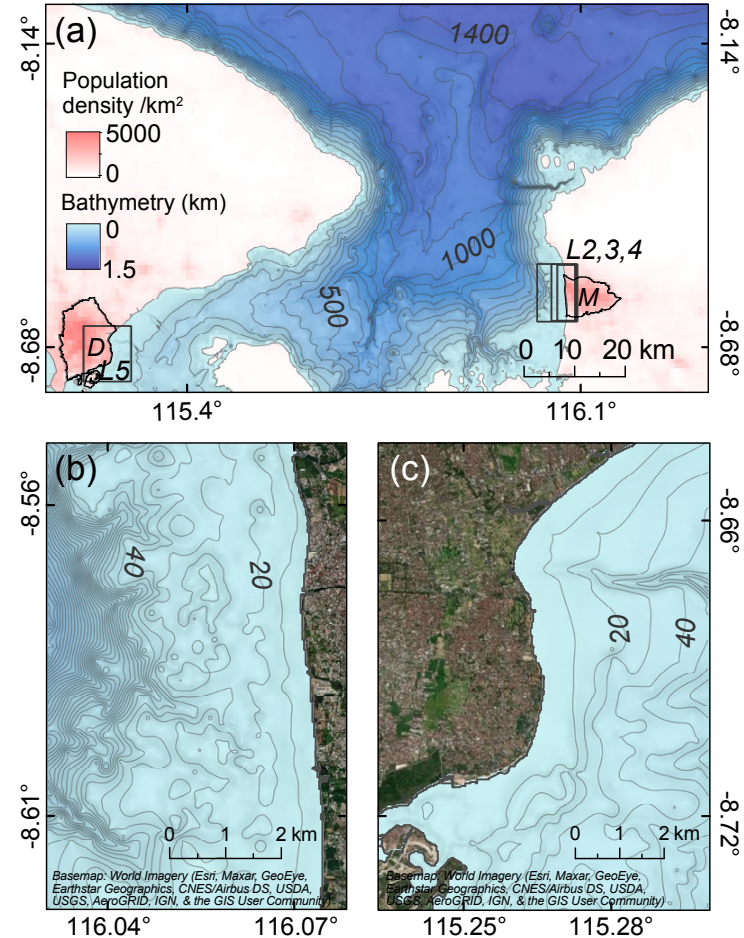

Figure 6: The generated bathymetry in the Lombok Strait. (a) The bathymetry has a north-south trending ridge along a narrow path between Bali and Lombok with its base at $1.4 \mathrm{~km}$ water depth, which is the deepest water depth in this region. The extent of (a) matches the extent of grid layer $\mathrm{L} 1$ used in the tsunami modelling. The finer grid layers $\mathrm{L2}$ L4 and L5 are focused on the populated cities of Mataram and Denpasar, respectively. M = Mataram, D = Denpasar. The population density is from worldpop.org (Bondarenko et al., 2020). (b) The linear coast of Mataram faces a rugged but gently dipping seafloor that suddenly steepens $\sim 3-4 \mathrm{~km}$ from the coast. (c) Denpasar city has a more complex coastline and a smoother seafloor. Basemaps - World Imagery.

\section{Results}

\subsection{Coseismic deformation and maximum wave height}

When slip occurs on the Flores Thrust ramp during an earthquake, the elastic response of the crust will lead to broad changes in the elevation of the ground surface. In the north, above the fault ramp, the seafloor will rise (uplifting any ocean column above), whereas the southern region will subside (Fig. 7a-c). Associated with this process, the islands of Bali and Lombok will tilt towards the south (Fig. 7a-c, 8a-c). As the initial sea surface deformation will have the same magnitude as the land deformation, the initial wave will be unnoticeable relative to the coast, which experiences the same vertical motion (Fig. 7d-f, 8d-f). The initial waves in our models correspond to tsunami energies of 1, 13, and $36 \mathrm{TJ}$ for Model A and 1, 7, and $20 \mathrm{TJ}$ for Model B for 1, 3, and $5 \mathrm{~m}$ of slip, respectively (Felix et al., 2021) 
The coseismic land change and tsunami heights are influenced by the distance from the fault and the shape of the coastline. Lombok and Bali have east-west trending headlands at $8.38^{\circ} \mathrm{S}$ latitude. In Lombok, the less protruding headland connects southwards to a north-south-trending linear coastline. In Bali, on the other hand, the headland protrudes further and connects to a southeast-facing coastline with a curved morphology. When the full fault slips (model A), the northern half of the islands, including the headlands at $8.38^{\circ} \mathrm{S}$, are uplifted. This uplift acts to counter any transient waves, including the initial wave, and results in a maximum relative wave height of generally $<0.5 \mathrm{~m}$ along the northern coasts. The exception is the headlands, where the waves can be much higher; here, the waves refract towards the concave coastlines, and the wave heights can reach $\sim-0.6-1.7 \mathrm{~m}$ high for $3-5 \mathrm{~m}$ of coseismic slip (Fig. 7d-e).

400 Along the southern coasts, on the other hand, coseismic subsidence acts to increase the relative tsunami heights. The subsidence in southern Lombok and Bali can reach as high as $\sim 0.3-0.4 \mathrm{~m}$ for $5 \mathrm{~m}$ of fault slip, $\sim 0.1-0.25 \mathrm{~m}$ for $3 \mathrm{~m}$ slip, and $<0.1 \mathrm{~m}$ for $1 \mathrm{~m}$ slip. We find that overall, the west coast of Lombok experiences higher tsunamis than the southeast coast of Bali, because it is closer to the tsunami source and the coastline is perpendicular to the source, making it more exposed to the propagating waves. The maximum tsunami height on the west coast of

405 Lombok is $\sim 1.6-3.7 \mathrm{~m}$ for 3-5 m of coseismic slip. On the other hand, the more distant and better protected southeastern coast of Bali has a maximum wave height of $\sim 0.7-2.2 \mathrm{~m}$ given the same slip amount, with slightly higher waves within the semi-enclosed bays (Figs. 7d-e).

When only the upper half of the fault ramp slips (model B), the uplift patch is narrower and the subsidence region 410 is broader, covering about three quarters of the coasts of Lombok and Bali. Unlike in model A, the headlands at $8.38^{\circ} \mathrm{S}$ are now within the area of subsidence. This results in an increase in the relative maximum wave height at the headlands, with $\sim 1.5-4 \mathrm{~m}$ high tsunamis for 3-5 m of coseismic slip (Fig. 8d-e). Similarly, the west coast of Lombok is hit by 1.5-3.4 m high tsunamis, while southeastern Bali experiences 0.5 to $2 \mathrm{~m}$ high tsunamis for 3$5 \mathrm{~m}$ of coseismic slip.

415

The two fault models generate similar maximum wave heights along the west coast of Lombok (Fig. 9), while the tsunamis generated by model A are slightly higher than model B along the southeastern coast of Bali (Fig. 10). In both models, however, we consistently observe higher tsunami waves in Lombok compared to Bali. This difference is best observed using the virtual tide gauge records situated near the cities of Mataram and Denpasar.

\subsection{Tsunami time series in Mataram, Lombok and Denpasar, Bali}

The tide gauge records show that the tsunami arrival times in Mataram and Denpasar are insensitive to the fault model geometries that we consider. The first and highest wave in Mataram arrives $<8$ minutes after the earthquake and it reaches its peak at $\sim 11$ minutes, followed by a drawdown at $\sim 15$ minutes. Three more waves reach the coast 425 at $\sim 20, \sim 35$ and 45 minutes (Fig. 11). The first wave in Mataram is $\sim 2.2-2.8 \mathrm{~m}$ high for $5 \mathrm{~m}$ slip, $\sim 1.4-1.7 \mathrm{~m}$ high for $3 \mathrm{~m}$ slip, and $\leq 0.6 \mathrm{~m}$ high for $1 \mathrm{~m}$ slip (Figs. $9 \& 11$ ). The height of the second wave is $\sim 1.9-2.4 \mathrm{~m}, \sim 1.2-1.5$ 
$\mathrm{m}, \sim 0.4-0.5 \mathrm{~m}$, respectively, for $5 \mathrm{~m}, 3 \mathrm{~m}$, and $1 \mathrm{~m}$ slip. The third wave is $\sim 0.3-1 \mathrm{~m}$ high for a $5 \mathrm{~m}$ slip, $\sim 0.2-0.6$ $\mathrm{m}$ for a $3 \mathrm{~m}$ slip, $\sim 0.1-0.3 \mathrm{~m}$ for $1 \mathrm{~m}$ slip. The last wave is $\sim 0.7-0.9, \sim 0.3-0.5$, and $\leq 0.2 \mathrm{~m}$, respectively, for 5,3 , and $1 \mathrm{~m}$ slips.

In Denpasar, the waves are smaller and take longer to arrive. The first wave arrives at $\sim 10-15$ minutes and reaches its peak at $\sim 30$ minutes. It is followed by a drawdown at $\sim 40$ minutes and a second wave at $\sim 45$ minutes (Fig. 11). As Denpasar is further from the tsunami source and has a complex coastline, its wave records are not as uniform as those along the linear coast of Mataram. For both fault models A and B, relatively higher tsunami waves are generated within the semi-enclosed bay in the northeast of Denpasar, while lower waves reach southwestwards along the concave coastline (Fig. 11). Although they have a similar trend, the wave heights generated by model A are slightly higher than model B. For model A, the maximum wave height generated is $\sim 1.1-1.3 \mathrm{~m}$ for $5 \mathrm{~m}$ slip, $\sim 0.7-0.8 \mathrm{~m}$ for $3 \mathrm{~m}$ slip, and $\sim 0.3 \mathrm{~m}$ for $1 \mathrm{~m}$ slip. For model B, the maximum wave height is $\sim 0.7-1.1 \mathrm{~m}$ for $5 \mathrm{~m}$ slip, $\sim 0.4-0.7 \mathrm{~m}$ for $3 \mathrm{~m}$ slip and $\leq 0.3 \mathrm{~m}$ for $1 \mathrm{~m}$ slip (Fig. 11).
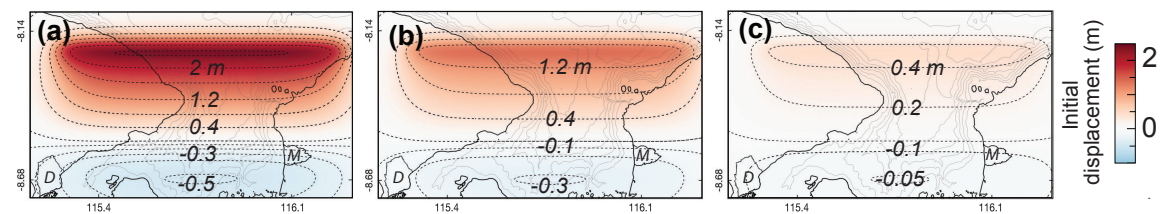

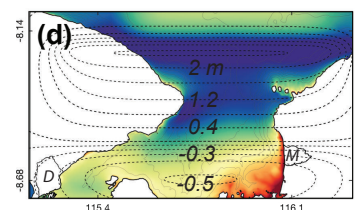

$5 \mathrm{~m}$ slip

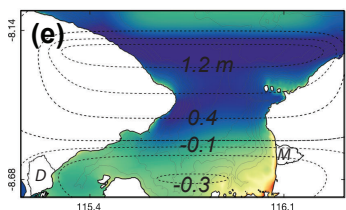

3m slip

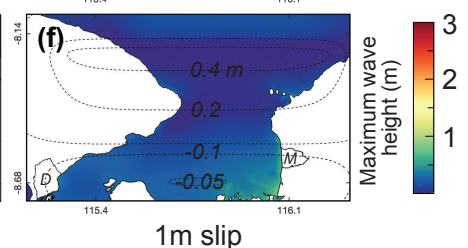

Figure 7: Initial surface deformation and maximum wave heights in $1 \mathrm{hr}$ generated by different slip amounts on the full 45-km wide fault ramp (model A). Upper panels (a-c): The coseismic deformation generated by (a) 5 m, (b) 3 m, and (c) $1 \mathrm{~m}$ fault slip events results in uplift in the northern half of the islands and subsidence in the south. Lower panels (d-f): Maximum sea surface displacements for (d) $5 \mathrm{~m}$, (e) $3 \mathrm{~m}$, and (f) $1 \mathrm{~m}$ fault slip events. Maps are adjusted to show wave heights relative to the post-earthquake land surface rather than initial sea level by subtracting the coseismic displacement (dashed contour lines). The west coast of Lombok is hit by higher tsunami waves than the southeastern coast of Bali. Polygons on land - cities of Denpasar, Bali and Mataram, Lombok. D = Denpasar, M = Mataram. 

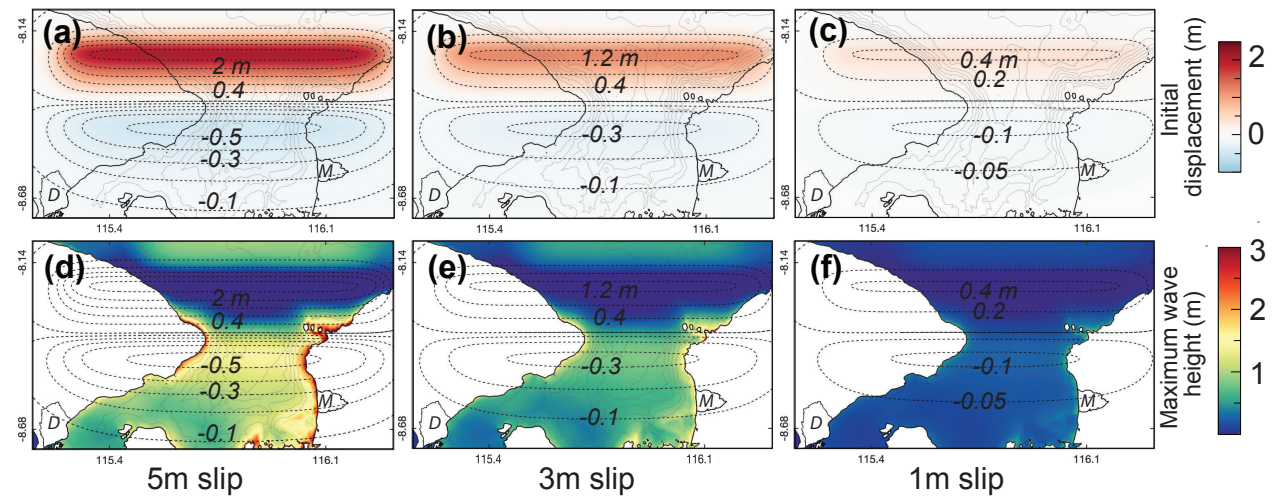

Figure 8: Initial surface deformation and maximum wave heights in $1 \mathrm{hr}$ generated by different slip amounts on the upper half of the fault ramp (model B). Upper panels (a-c): The coseismic deformation generated by (a) $5 \mathrm{~m}$, (b) $3 \mathrm{~m}$, and (c) $1 \mathrm{~m}$ fault slip events results in a narrow uplift patch in the north and broader subsidence in the south. Lower panels (d-f): Maximum sea surface displacements for (d) $5 \mathrm{~m}$, (e) $3 \mathrm{~m}$, and (f) $1 \mathrm{~m}$ fault slip events. Maps are adjusted to show wave heights relative to the post-earthquake land surface rather than initial sea level by subtracting the coseismic displacement (dashed contour lines). The highest waves are concentrated around the headlands of Lombok and Bali at $8.38^{\circ} \mathrm{S}$ and the mid-west coast of Lombok. Polygons on land - cities of Denpasar, Bali and Mataram, Lombok. $\mathbf{D}$ = Denpasar, $\mathbf{M}=$ Mataram.
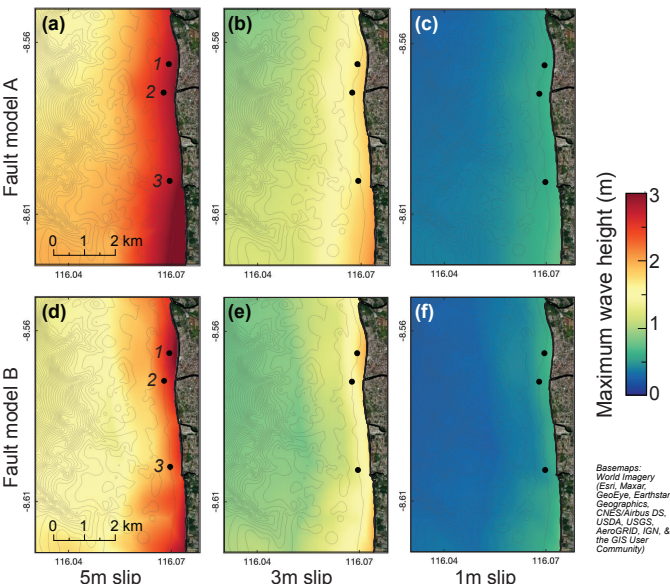

Figure 9: Maximum wave heights in Mataram generated by slip on fault models A (a-c) and B (d-f). The $5 \mathrm{~m}$ slip models (a,d) generate wave heights of $\sim 2.5$ to $3.3 \mathrm{~m}$; the $3 \mathrm{~m}$ slip models (b,e) generate $\sim 1.5$ to $2.1 \mathrm{~m}$ high waves; the $1 \mathrm{~m}$ slip models $(c, f)$ generate $\sim 0.6$ to $0.7 \mathrm{~m}$ high waves. Basemaps - World Imagery. Dots - tide gauges. 

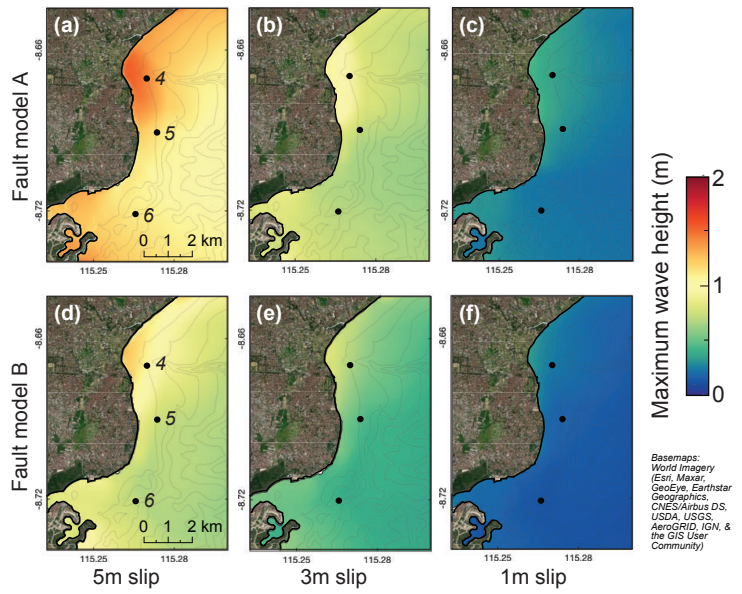

Figure 10: Maximum wave heights in Denpasar generated by slip on fault models A (a-c) and B (d-f). The highest tsunami wave heights are located within the semi-enclosed bay on the northeast coast. The maximum wave heights near Denpasar for model A range from $\sim 1.1$ to $1.5 \mathrm{~m}$ for $5 \mathrm{~m}$ slip (a), $\sim 0.7$ to $1.1 \mathrm{~m}$ for $3 \mathrm{~m}$ slip (b), and $\sim 0.3$ to $0.4 \mathrm{~m}$ for $1 \mathrm{~m}$ slip (c). For fault model B, the maximum wave heights are $\sim 0.7$ to $1.2 \mathrm{~m}$ for $5 \mathrm{~m}$ slip (d) $\sim 0.4$ to $0.8 \mathrm{~m}$ for $3 \mathrm{~m}$ slip (e), and $\sim 0.2$ to $0.3 \mathrm{~m}$ for $1 \mathrm{~m}$ slip (f). Basemaps - World Imagery. Dots - tide gauges.
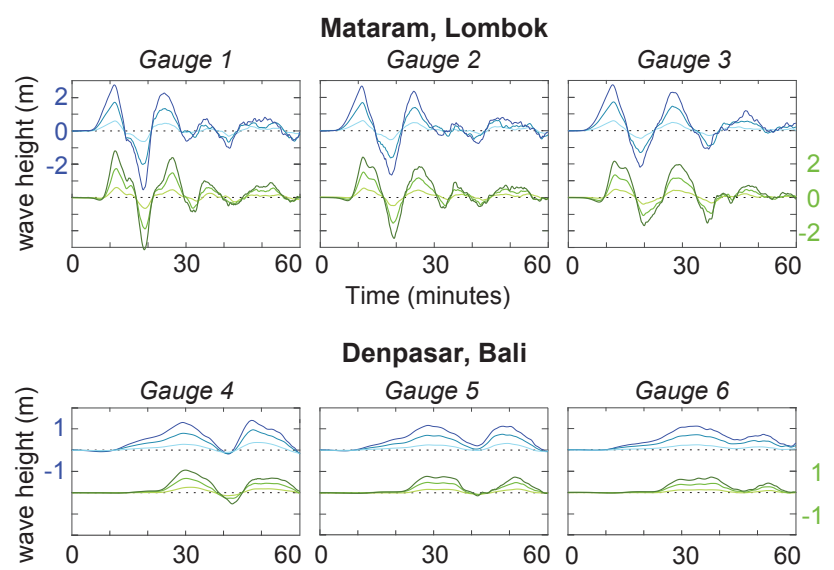

Denpasar, Bali
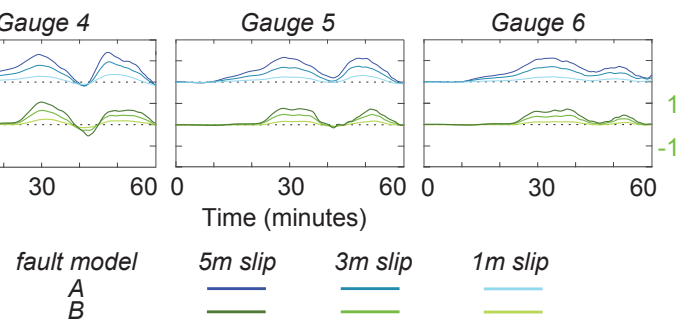

Figure 11: Sea surface deformation generated by fault models $A$ and $B$ recorded at virtual tide gauges located along the $10 \mathrm{~m}$ water depth contours offshore Mataram (gauges 1 to 3) and Denpasar (gauges 4 to 6). The records for fault 
models $A$ and $B$ in Mataram are similar in terms of wave heights and arrival times. In Denpasar, the arrival times are similar for both models, but the wave heights are higher for model A. After the earthquake, the first tsunami in Mataram arrives at $<8$ minutes, while in Denpasar it arrives at $\sim 10-15$ minutes. The peak of the first wave is at $\sim 11$ minutes and $\sim 30$ minutes in Mataram and Denpasar, respectively.

\subsection{Inundation in Mataram, Lombok}

Tsunami waves of a given height at the coastline can have variable impact depending on the topography and

465 infrastructure on land. Because inundation modeling requires a detailed Digital Surface Model for accurate results and significant computational time, we limit the inundation modeling to the city of Mataram, Lombok, because this region is densely populated (Fig. 6) and is exposed to the highest waves in our tsunami models. We run the modeling for the highest value of fault slip $(5 \mathrm{~m})$ for fault model A (full rupture) to represent our worst-case scenario.

Based on our results, $5 \mathrm{~m}$ of fault slip generates two $>2 \mathrm{~m}$ high waves followed by two lower waves that hit the coast at Mataram city (Fig. 11). These waves inundate Mataram with flow depths of generally $\leq 1.5 \mathrm{~m}$ but can reach as high as $3 \mathrm{~m}$ on the southern coast (Figs. 12 and 13). The extent of inundation is $\sim 55-140 \mathrm{~m}$ along the northern to the middle parts of the coast; in the south, it reaches $\sim 230 \mathrm{~m}$. This much wider extent in the south

475 correlates with a lower density of structures. We interpret that the presence of closely packed structures in the north limits the inundation further inland. Our results are based on the model assumption that these structures can withstand the flow; in a real tsunami event, some structures could be destroyed (e.g., 2011 Tohoku earthquake and tsunami, Mori et al., 2013), which could reduce flow resistance and increase the inundation distance.

480 The inundation has limited extent where the beach is narrow and there are dense structures near the coast. For instance, along the northern (Figs. 12a-b) and mid-southern coasts (Figs 13a-b), inundation is limited to within the $\sim 15-20$ m wide beach, and the closely packed residential structures just behind the beach are not inundated. At industrial sites where there are more open spaces (Figs. 12a-b and 13a-b), the inundation extent can reach to 95-140 m (Figs. 12a-d). When the beach is wider and the structures are further from the coast, the inundation extends further inland (Figs. 12c-d and 13c-d). We note that in our model, clustered vegetation on the beach is represented in the DSM as a solid barrier, and thus is able to entirely block the flow (upper part of Fig. 12c-d). In reality, clustered vegetation can slow but not completely obstruct the flow; the inundation extent at this site is therefore likely underestimated. Our results may be more realistic in regions where vegetation is absent, as in the lower part of Fig. 13a-b, where we model $\sim 175 \mathrm{~m}$ inundation. Along the southern coast, the beach is generally

$490 \quad 20-40 \mathrm{~m}$ wide and most of the area is farmland; with more open space, the inundation is able to reach $\sim 230 \mathrm{~m}$ inland (Figs. 13c-d). 

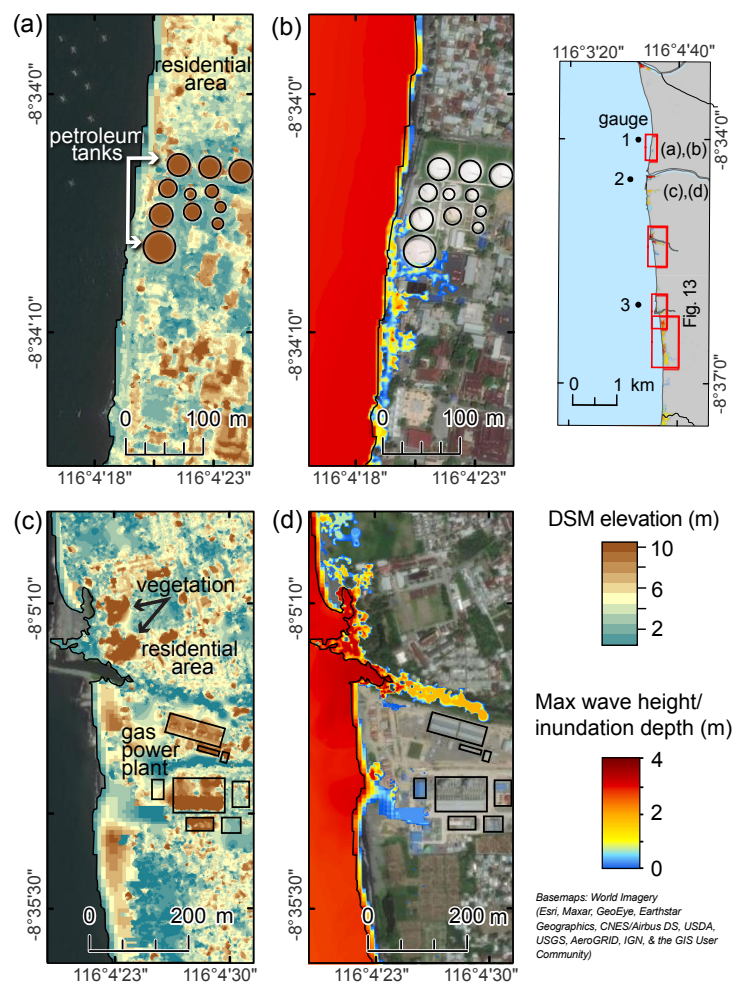

DSM elevation $(\mathrm{m})$

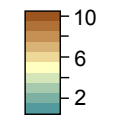

Max wave height/ inundation depth $(\mathrm{m})$

Figure 12: The DSM elevation and inundation on the northern coast of Mataram associated with 5 m of coseismic slip on the Flores thrust ramp (model A) overlain on World Imagery. Flow depth is generally $\leq 1.5 \mathrm{~m}$. (a-b) The inundation extent is limited by the high density of structures in residential areas. The inundation reaches $\sim 95 \mathrm{~m}$ at the industrial site (circular features are petroleum tanks), where there are more open spaces. (c-d) Inundation may be underestimated in regions where vegetation clusters act in the model as wide barriers to flow but may be more porous, as shown in the upper half of the map. In the area of the gas power plant, where there is less vegetation and the structures are more widely spaced, the inundation extent is $\sim 140 \mathrm{~m}$. Right image - location map of figures. 

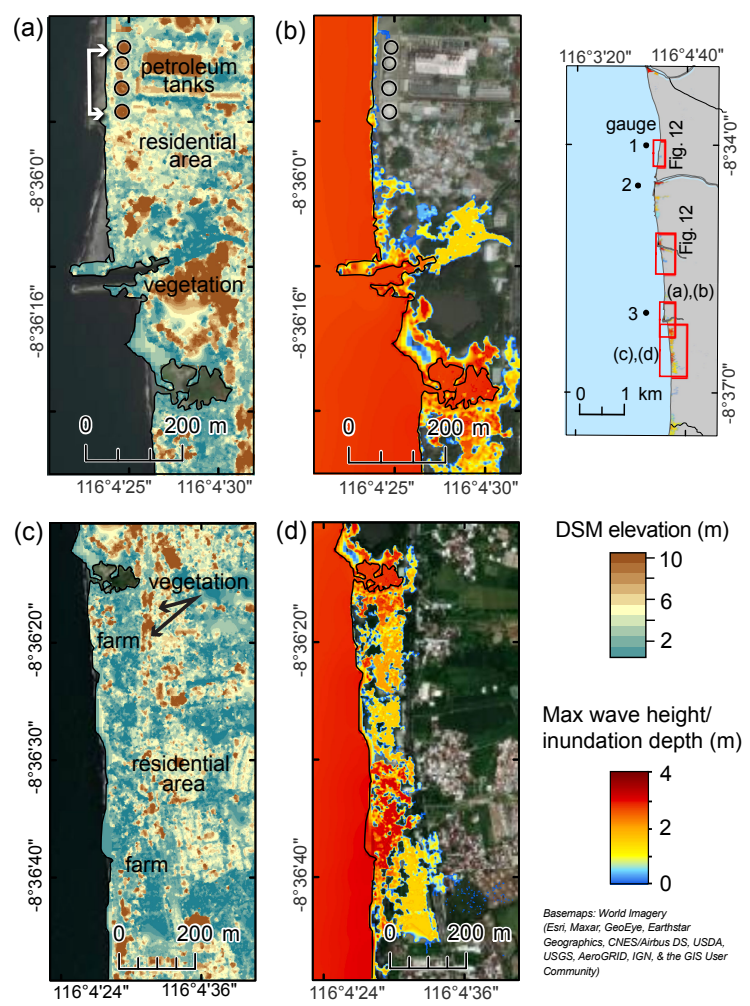

DSM elevation ( $m$ )

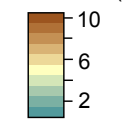

Max wave height

inundation depth $(\mathrm{m})$

4

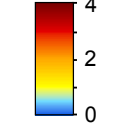

Basemaps: World Imagory
(Esti, Maxar, GooEye, Earthstar

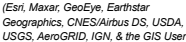

Figure 13: The DSM elevation and inundation on the southern coast of Mataram associated with $5 \mathrm{~m}$ of coseismic slip on the Flores thrust ramp (model A) overlain on World Imagery. (a-b) To the south of the industrial site (with petroleum tanks), the inundation depth is $\leq 1.5 \mathrm{~m}$ and the inundation extent is $\sim 175 \mathrm{~m}$. (c-d) In the south, inundation is more extensive, likely because of the lower density of structures and wider open area (beach and farmland). The inundation depth is generally $\mathbf{2 - 3} \mathrm{m}$ and the extent reaches to $\sim 230 \mathrm{~m}$. Right image - location map of figures.

\section{Conclusions}

The Flores Thrust is an active south-dipping back-arc fault system traversing north of the Lesser Sunda Islands.

The 2018 Lombok earthquake sequence and prior historical events show that the western part of the fault zone is capable of generating tsunamigenic earthquakes. In this work, we study the tsunami potential associated with coseismic slip on the blind fault ramp below Lombok Strait, located between the islands of Lombok and Bali. We focus on the tsunami patterns near the capital cities of Mataram, Lombok and Denpasar, Bali, which both lie on the coasts facing the strait. Our modeling is based on a geologically constrained model of the fault, informed by

510 the 2018 earthquake sequence. Tsunami propagation is modeled using a high-resolution bathymetry dataset generated by combining data points from the global GEBCO dataset with sounding data digitized from the official nautical charts of Indonesia, interpolated using the Topo to Raster tool in ArcGIS.

Our results show that fault rupture in this region with 1-5 $\mathrm{m}$ of coseismic slip could trigger a tsunami that would

515 hit Mataram, Lombok in $\sim 11$ minutes and Denpasar, Bali in $\sim 30$ minutes with multiple waves. Furthermore, both cities would experience coseismic subsidence of $20-40 \mathrm{~cm}$, exacerbating their exposure to the tsunami hazard and 
leading to more long-lasting coastal vulnerability. The maximum wave heights in Mataram are 1.5 to $3.3 \mathrm{~m}$ for 3 $5 \mathrm{~m}$ of coseismic slip, while Denpasar has maximum wave heights of 0.7 to $1.5 \mathrm{~m}$. Overall, the coast along Mataram city is more prone than Denpasar to high tsunamis arriving quickly.

Because Mataram experiences higher wave heights, we also modelled the inundation in this region for our worstcase scenario ( $5 \mathrm{~m}$ slip) using a high-resolution DSM. We found that the inundation extends for $\sim 55-140 \mathrm{~m}$ inland with a maximum flow depth of $\sim 2-3 \mathrm{~m}$, and, except in the region just south of the city, where the inundation reaches $230 \mathrm{~m}$. This difference in inundation extent appears to be primarily influenced by the structures present near the coast, which are denser in the north. However, if structures are destroyed by flow, inundation could reach further inland.

Because of the proximity of the Flores thrust ramp to the coasts of Lombok and Bali, associated tsunamis would hit within $<15$ minutes after the earthquake. This early tsunami arrival would mean little time for evacuation. In the case of the 2018 Lombok earthquake, the residents of northern Lombok started evacuation only after a government announcement, and the evacuation took at least 20 minutes (Tsimopoulou et al., 2020). For a potential tsunami in Mataram caused by slip on the Flores thrust, there is insufficient time to wait for an announcement after the earthquake. Hence, raising community awareness about earthquake-generated tsunamis and evacuation plans is important, so that residents will know to respond immediately after experiencing strong ground shaking.

535 Furthermore, the initial polarity of the waves would be positive, and thus there would be no warning signal from drawdown prior to inundation. In addition, a second high wave would hit Mataram coast at $\sim 20$ minutes, emphasizing the need for continued heightened alert following the first inundation.

We finally note that some of the structures built along the coast are industrial, with several petroleum tanks and a 540 gas power plant. The impacts of natural disasters can be multiplied when natural events trigger industrial events ('Natural Hazards Triggering Technological Disasters,' or Natech) (Cruz and Suarez-Paba, 2019). Tsunamis in particular have a history of causing Natech events (e.g. (Suppasri et al., 2021); for instance, the 2011 Mw9.1 Tohoku earthquake and tsunami led to not only meltdown at the Fukushima-Daichi nuclear power plant, but also fires, explosions, and hazardous materials release at industrial sites (Krausmann and Cruz, 2013). In Mataram, damage to the petroleum tanks, power plant, and other industrial equipment by groundshaking or inundation could trigger Natech events, including fires, explosions, and pollution of the coastal water and associated ecological damage. Evaluating these sites to understand and strengthen their resilience to these hazards should be a priority.

While most tsunami modeling studies in Indonesia have focused on the hazard associated with large tsunamis

550 triggered by megathrust ruptures, such as the devastating 2004 Indian Ocean earthquake and tsunami (e.g. Wang and Liu, 2007), we highlight here the hazard associated with smaller, local events caused by slip on a back-arc thrust system. One of the challenges with local studies is the need for detailed and accurate fault models and bathymetry datasets. We show that geological information such as regional and nearby seismicity can be combined with bathymetry, topography, and seismic reflection data to model fault geometry, and that a high-resolution bathymetry dataset can be generated by combining globally available bathymetric data with sounding measurements collected for navigation purposes. Specifically, for earthquake-triggered tsunamis in Indonesia, the 
official nautical charts for Indonesia provide dense measurements offshore shallow coastal cities. Integrating these datasets can provide more accurate forecasts and hazard estimations for both tsunami wave height and arrival time, for local and regional studies, and could be replicated for other fault systems and areas.

560

\section{DATA AVAILABILITY}

The animation of the tsunami propagation for the $5 \mathrm{~m}$ coseismic slip on the full fault ramp can be accessed at https://researchdata.ntu.edu.sg/privateurl.xhtml?token=ed262ac9-0649-4d39-9c34-104c0e93f6f1

The inundation model for Mataram, Lombok can be accessed at

https://researchdata.ntu.edu.sg/privateurl.xhtml?token=0b2a3b5b-2731-4394-8442-fa5b24a04642

\section{AUTHOR CONTRIBUTION}

RPF, JAH and KEB conceptualized the research. RPF conducted the modeling and the formal analysis. JAH and KEB acquired the funding. JAH supervised the overall work. JAH, KEB and KLH assisted with the fault model 570 setup. LL and ADS assisted with the tsunami modelling. RPF generated the figures. RPF and JAH wrote the original draft. JAH, KEB, KHL, LL and ADS reviewed and edited the manuscript.

\section{COMPETING INTERESTS}

The authors declare no competing interests.

575

\section{ACKNOWLEDGMENTS}

The maps in this paper were made using ArcGIS ${ }^{\circledR}$ software by Esri. The World Ocean Base map is attributed to Esri, GEBCO, NOAA, Garmin, HERE, and other contributors. The World Imagery basemap is attributed to Esri, Maxar, Earthstar Geographics, USDA FSA, USGS, Aerogrid, IGN, IGP, and the GIS User Community. The 580 ArcGIS ${ }^{\circledR}$ and ArcMap $^{\mathrm{TM}}$ are the intellectual property of Esri and are used herein under license. Copyright ${ }^{C}$ Esri. All rights reserved. We would like to thank Rishav Mallick for helping in creating figure 4 using the Unicycle code (Moore et al., 2019).

This research was supported by the Earth Observatory of Singapore via its funding from the National Research Foundation Singapore and the Singapore Ministry of Education under the Research Centres of Excellence initiative. This work comprises EOS contribution number 408. The project was also supported by National Natural Science Foundation China (No 41976197).

\section{REFERENCES}

Afif, H., and A. Cipta, 2015, Tsunami hazard map in eastern Bali, AIP Conf. Proc., 1658, no. April, doi: $10.1063 / 1.4915041$.

Beckers, J., and T. Lay, 1995, Very broadband seismic analysis of the 1992 Flores, Indonesia, earthquake (Mw = 7.9), J. Geophys. Res., 100, no. B9, doi: 10.1029/95jb01689.

Van Bemmelen, R. W., 1949, General Geology of Indonesia and adjacent archipelagoes, Geol. Indones. 
Biasi, G. P., and R. J. Weldon, 2006, Estimating Surface Rupture Length and Magnitude of Paleoearthquakes from Point Measurements of Rupture Displacement, Bull. Seismol. Soc. Am., 96, no. 5, 1612-1623, doi: $10.1785 / 0120040172$.

Boekschoten, G. J., M. B. Best, and K. S. Putra, 2000, Balinese reefs in historical context, in Proceedings 9th International Coral Reef Symposium, Citeseer, 23-27.

Bondarenko, M., D. Kerr, A. Sorichetta, and A. Tatem, 2020, Census/projection-disaggregated gridded population datasets for 189 countries in 2020 using Built-Settlement Growth Model (BSGM) outputs, doi: $10.5258 /$ SOTON/WP00684.

Bowin, C., G. M. Purdy, C. Johnston, G. Shor, H. M. S. Lawver, L. Hartono, and P. Jezek, 1980, Arc-Continent Collision in Banda Sea Region, Am. Assoc. Pet. Geol. Bull., 64, doi: 10.1306/2F9193CD-16CE-11D7$8645000102 \mathrm{C} 1865 \mathrm{D}$.

Chau, K. T., and K. T. S. Lam, 2015, Field observations and numerical simulations of the 2011 Tohoku tsunami using COMCOT, Comput. Methods Recent Adv. Geomech. - Proc. 14th Int. Conf. Int. Assoc. Comput. Methods Recent Adv. Geomech. IACMAG 2014, 1841-1846, doi: 10.1201/b17435-326.

Cruz, A. M., and M. C. Suarez-Paba, 2019, Advances in Natech research: An overview, Prog. Disaster Sci., 1, 100013, doi: 10.1016/j.pdisas.2019.100013.

Darmawan, H. et al., 2020, Topography and structural changes of Anak Krakatau due to the December 2018 catastrophic events, Indones. J. Geogr., 52, no. 3, 402, doi: 10.22146/ijg.53740.

Dewey, J. F., and J. M. Bird, 1970, Mountain belts and the new global tectonics, J. Geophys. Res., 75, no. 14, 2625-2647, doi: 10.1029/JB075i014p02625.

Felix, R. P., J. A. Hubbard, J. D. P. Moore, and A. D. Switzer, 2021, The Role of Frontal Thrusts in Tsunami Earthquake Generation, Bull. Seismol. Soc. Am., doi: 10.1785/0120210154.

Fraser, S. A., W. L. Power, X. Wang, L. M. Wallace, C. Mueller, and D. M. Johnston, 2014, Tsunami inundation in Napier, New Zealand, due to local earthquake sources, Nat. Hazards, 70, no. 1, 415-445, doi: 10.1007/s11069-013-0820-x.

Griffin, J. et al., 2015, An evaluation of onshore digital elevation models for modeling tsunami inundation zones, Front. Earth Sci., 3, doi: 10.3389/feart.2015.00032.

Hall, R., and W. Spakman, 2015, Mantle structure and tectonic history of SE Asia, Tectonophysics, 658, 14-45, doi: $10.1016 /$ j.tecto.2015.07.003.

Hamilton, W., 1979, Tectonics of the Indonesian region, US Government Printing Office.

Hamzah, L., N. Puspito, and F. Imamura, 2000, Tsunami Catalog Indonesia.pdf, 25-43.

Hanks, T. C., 2002, A Bilinear Source-Scaling Model for M-log A Observations of Continental Earthquakes, Bull. Seismol. Soc. Am., 92, no. 5, 1841-1846, doi: 10.1785/0120010148.

Hanks, T. C., and W. H. Bakun, 2008, M-logA Observations for Recent Large Earthquakes, Bull. Seismol. Soc. Am., 98, no. 1, 490-494, doi: 10.1785/0120070174.

Hill, E. M. et al., 2012, The 2010 Mw 7.8 Mentawai earthquake: Very shallow source of a rare tsunami earthquake determined from tsunami field survey and near-field GPS data, J. Geophys. Res. Solid Earth, 117, no. 6, doi: 10.1029/2012JB009159.

635 Horspool, N., I. Pranantyo, J. Griffin, H. Latief, D. H. Natawidjaja, W. Kongko, A. Cipta, B. Bustaman, S. D. Anugrah, and H. K. Thio, 2014, A probabilistic tsunami hazard assessment for Indonesia, Nat. Hazards 
Earth Syst. Sci., 14, no. 11, 3105-3122, doi: 10.5194/nhess-14-3105-2014.

Hutchinson, M. F., 1989, A new procedure for gridding elevation and stream line data with automatic removal of spurious pits, J. Hydrol., 106, nos. 3-4, 211-232, doi: 10.1016/0022-1694(89)90073-5.

Imamura, F., and M. Kikuchi, 1994, Moment release of the 1992 Flores Island earthquake inferred from tsunami and teleseismic data, Sci. Tsunami Hazards, 12, 67-76.

Kaiser, G., L. Scheele, A. Kortenhaus, F. Løvholt, H. Römer, and S. Leschka, 2011, The influence of land cover roughness on the results of high resolution tsunami inundation modeling, Nat. Hazards Earth Syst. Sci., 11, no. 9, 2521-2540, doi: 10.5194/nhess-11-2521-2011.

645 Kardoso, R., and A. A. C. Dewi, 2021, Tsunami inundation maps in Mataram City based on tsunami modeling, in Proceeding International Conference on Science (ICST), 273-278.

Koulali, A., S. Susilo, S. McClusky, I. Meilano, P. Cummins, P. Tregoning, G. Lister, J. Efendi, and M. A. Syafi'I, 2016, Crustal strain partitioning and the associated earthquake hazard in the eastern Sunda-Banda Arc, Geophys. Res. Lett., 43, no. 5, 1943-1949, doi: 10.1002/2016GL067941.

Krausmann, E., and A. M. Cruz, 2013, Impact of the 11 March 2011, Great East Japan earthquake and tsunami on the chemical industry, Nat. Hazards, 67, no. 2, 811-828, doi: 10.1007/s11069-013-0607-0.

Kulikov, E. A., V. K. Gusiakov, A. A. Ivanova, and B. V. Baranov, 2016, Numerical tsunami modeling and the bottom relief, Moscow Univ. Phys. Bull., 71, no. 6, 527-536, doi: 10.3103/S002713491605012X.

Kurniawan, T., and A. F. Laili, 2019, Penentuan Area Terdampak" Ketinggian Maksimum Tsunami" di Pulau Bali Berdasarkan Potensi Gempabumi Pembangkit Tsunami Pada Segmen Megathrust Sumba, J. Dialog dan Penanggulangan Bencana, 10, no. 1, 93-104.

Liu, Philip L.F., Y. S. Cho, M. J. Briggs, U. Kanoglu, and C. E. Synolakis, 1995, Runup of solitary waves on a circular Island, J. Fluid Mech., 302, no. 37, 259-285, doi: 10.1017/S0022112095004095.

Liu, P.L.F., Y. S. Cho, S. B. Yoon, and S. N. Seo, 1995, Numerical Simulations of the 1960 Chilean Tsunami Propagation and Inundation at Hilo, Hawaii, 99-115.

Løvholt, F., D. Kühn, H. Bungum, C. B. Harbitz, and S. Glimsdal, 2012, Historical tsunamis and present tsunami hazard in eastern Indonesia and the southern Philippines, J. Geophys. Res. Solid Earth, 117, no. B9, doi: 10.1029/2012JB009425.

Lythgoe, K., M. Muzli, K. Bradley, T. Wang, A. D. Nugraha, Z. Zulfakriza, S. Widiyantoro, and S. Wei, 2021, Thermal squeezing of the seismogenic zone controlled rupture of the volcano-rooted Flores Thrust, Sci. Adv., 7, no. 5, 1-9, doi: 10.1126/SCIADV.ABE2348.

Marks, K. M., and W. H. F. Smith, 2006, An Evaluation of Publicly Available Global Bathymetry Grids, Mar. Geophys. Res., 27, no. 1, 19-34, doi: 10.1007/s11001-005-2095-4.

McCaffrey, R., and J. Nabelek, 1987, Earthquakes, gravity, and the origin of the Bali Basin: An example of a Nascent Continental Fold-and-Thrust Belt, J. Geophys. Res., 92, no. B1, 441, doi: 10.1029/JB092iB01p00441.

Moore, J. D. P., S. Barbot, E. Lindsey, S. Masuti, and J. Muto, 2019, jdpmoore/unicycle: Unicycle, doi: 10.5281/ZENODO.4471162.

Musson, R. M. W., 2012, A provisional catalogue of historical earthquakes in Indonesia, Br. Geol. Surv.

675 Nguyen, N., J. Griffin, A. Cipta, and P. R. Cummins, 2015, Indonesia’s Historical Earthquakes: Modelled examples for improving the national hazard map. 
NOAA, 2021, National Geophysical Data Center / World Data Service: NCEI/WDS Global Historical Tsunami Database. NOAA National Centers for Environmental Information. doi:10.7289/V5PN93H7.

Okada, Y., 1992, Internal deformation due to shear and tensile faults in a half-space, Bull. Seismol. Soc. Am., 82 , no. 2, 1018-1040.

Okal, E. A., and J. C. Borrero, 2011, The "tsunami earthquake" of 1932 June 22 in Manzanillo, Mexico: Seismological study and tsunami simulations, Geophys. J. Int., 187, no. 3, 1443-1459, doi: 10.1111/j.1365-246X.2011.05199.x.

Pradjoko, E., L. Wardani, H. Wardani, H. Sulistiyono, and S. Sulistiyono, 2018, The prediction of tsunami travel time to Mataram City Indonesia based on North Lombok earthquake as the initial condition, MATEC Web Conf., 229, 4-8, doi: 10.1051/matecconf/201822904007.

Pranantyo, I. R., M. Heidarzadeh, and P. R. Cummins, 2021, Complex tsunami hazards in eastern Indonesia from seismic and non-seismic sources: Deterministic modelling based on historical and modern data, Geosci. Lett., 8, no. 1, 20, doi: 10.1186/s40562-021-00190-y.

Rakowsky, N., A. Androsov, A. Fuchs, S. Harig, A. Immerz, S. Danilov, W. Hiller, and J. Schröter, 2013, Operational tsunami modelling with TsunAWI - Recent developments and applications, Nat. Hazards Earth Syst. Sci., 13, no. 6, 1629-1642, doi: 10.5194/nhess-13-1629-2013.

Rastogi, B. K., and R. K. Jaiswal, 2006, A Catalog of Tsunamis in the Indian Ocean, Sci. Tsunami Hazards, 25, no. $3,128-143$.

Regnier, M., S. Calmant, B. Pelletier, Y. Lagabrielle, and G. Cabioch, 2003, The M w 7.5 1999 Ambrym earthquake, Vanuatu: A back arc intraplate thrust event, Tectonics, 22, no. 4, n/a-n/a, doi: $10.1029 / 2002$ TC001422.

Rusli, Irjan, and A. Rudyanto, 2012, Pemodelan Tsunami Sebagai Bahan Mitigasi Bencana Studi Kasus Sumenep Dan Kepulauannya, J. Neutrino, doi: 10.18860/neu.v0i0.1639.

Salman, R. et al., 2020, Cascading partial rupture of the flores thrust during the 2018 lombok earthquake sequence, indonesia, Seismol. Res. Lett., 91, no. 4, 2141-2151, doi: 10.1785/0220190378.

Satake, K., 1988, Effects of bathymetry on tsunami propagation: Application of ray tracing to tsunamis, Pure Appl. Geophys. PAGEOPH, 126, no. 1, 27-36, doi: 10.1007/BF00876912.

Satake, K., 1995, Linear and nonlinear computations of the 1992 Nicaragua earthquake tsunami, Pure Appl. Geophys., 144, nos. 3-4, 455-470, doi: 10.1007/BF00874378.

Silver, E. A., N. A. Breen, H. Prasetyo, and D. M. Hussong, 1986, Multibeam study of the Flores Backarc Thrust Belt, Indonesia, J. Geophys. Res. Solid Earth, 91, no. B3, 3489-3500, doi: 10.1029/JB091iB03p03489.

Silver, E. A., and D. L. Reed, 1988, Backthrusting in accretionary prism, J. Geophys. Res., 93, no. B4, 31163126.

Silver, E. A., D. Reed, R. McCaffrey, and Y. Joyodiwiryo, 1983, Back arc thrusting in the Eastern Sunda Arc, Indonesia: A consequence of arc-continent collision, J. Geophys. Res. Solid Earth, 88, no. B9, 7429-7448, doi: 10.1029/JB088iB09p07429.

Suardana, A. A. M. A. P., D. N. Sugianto, and M. Helmi, 2019, Study of Characteristics and the Coverage of Tsunami Wave Using 2D Numerical Modeling in the South Coast of Bali, Indonesia, Indones. J. Ocean. Geogr., 13, 237-250. 
Suárez, G., M. Pardo, J. Domínguez, L. Ponce, W. Montero, I. Boschini, and W. Rojas, 1995, The Limón, Costa

Rica earthquake of April 22, 1991: Back arc thrusting and collisional tectonics in a subduction environment, Tectonics, 14, no. 2, 518-530, doi: 10.1029/94TC02546.

Suppasri, A., E. Maly, M. Kitamura, Syamsidik, G. Pescaroli, D. Alexander, and F. Imamura, 2021, Cascading disasters triggered by tsunami hazards: A perspective for critical infrastructure resilience and disaster risk reduction, Int. J. Disaster Risk Reduct., 66, 102597, doi: 10.1016/j.ijdrr.2021.102597.

Tri Laksono, F. A., M. R. Aditama, R. Setijadi, and G. Ramadhan, 2020, Run-up Height and Flow Depth Simulation of the 2006 South Java Tsunami Using COMCOT on Widarapayung Beach, IOP Conf. Ser. Mater. Sci. Eng., 982, 012047, doi: 10.1088/1757-899X/982/1/012047.

Tsimopoulou, V., T. Mikami, T. T. Hossain, H. Takagi, M. Esteban, and N. A. Utama, 2020, Uncovering unnoticed small-scale tsunamis: field survey in Lombok, Indonesia, following the 2018 earthquakes, Nat. Hazards, 103, no. 2, 2045-2070, doi: 10.1007/s11069-020-04071-z.

Tsuji, Y., H. Matsutomi, F. Imamura, M. Takeo, Y. Kawata, M. Matsuyama, T. Takahashi, Sunarjo, and P. Harjadi, 1995, Damage to coastal villages due to the 1992 Flores Island earthquake tsunami, Pure Appl. Geophys. PAGEOPH, 144, nos. 3-4, 481-524, doi: 10.1007/BF00874380.

Wang, X., and P. L.-F. Liu, 2007, Numerical Simulations of the 2004 Indian Ocean Tsunamis - Coastal Effects, J. Earthq. Tsunami, 01, no. 03, 273-297, doi: 10.1142/s179343110700016x.

Wang, X., and W. Power, 2011, COMCOT: a Tsunami Generation Propagation and Run-up Model.

Wells, D. L., and K. J. Coppersmith, 1994, New empirical relationships among magnitude, rupture length, rupture width, rupture area, and surface displacement, Bull. Seismol. Soc. Am., 84, no. 4, 974-1002.

Wibowo, S. B., D. S. Hadmoko, Y. Isnaeni, N. M. Farda, A. F. S. Putri, I. W. Nurani, and S. H. Supangkat, 2021, Spatio-Temporal Distribution of Ground Deformation Due to 2018 Lombok Earthquake Series, Remote Sens., 13, no. 11, 2222, doi: 10.3390/rs13112222.

Wibowo, M., W. Kongko, W. Hendriyono, and S. Karima, 2021, Tsunami Hazard Potential Modeling as Tourism Development Considerations in the North of Lombok Strait, IOP Conf. Ser. Earth Environ. Sci., 832, no. 1, 012047, doi: 10.1088/1755-1315/832/1/012047.

Wilson, K. M., and H. E. Power, 2020, Tsunami Modelling with Static and Dynamic Tides in Drowned River Valleys with Morphological Constrictions, Pure Appl. Geophys., 177, no. 3, 1595-1616, doi: 10.1007/s00024-019-02411-0.

Yang, X., S. C. Singh, and A. Tripathi, 2020, Did the Flores backarc thrust rupture offshore during the 2018 Lombok earthquake sequence in Indonesia?, Geophys. J. Int., 221, no. 2, 758-768, doi: 10.1093/gji/ggaa018.

Yeh, H., F. Imamura, C. Synolakis, Y. Tsuji, P. Liu, and S. Shi, 1993, The Flores Island tsunamis, Eos, Trans. Am. Geophys. Union, 74, no. 33, 369-373, doi: 10.1029/93EO00381. 